\title{
HISTORICAL AMNESIA AND ITS CONSEQUENCES - THE NEED TO BUILD HISTORIES OF PRACTICE
}

\author{
Sioban Nelson ${ }^{1}$
}

\begin{abstract}
${ }^{1}$ Registered Nursing, PhD. Professor and Dean Lawrence S Bloomberg Faculty of Nursing, University of Toronto. Toronto, Canada. E-mail: sioban.nelson@utoronto.ca
\end{abstract}

\begin{abstract}
This paper focuses on two key themes: the role of history as a witness to key events, moments, or shifts in history; and the role of history in the on-going development of identity - identity of individuals, of groups, of nations or generations. I will conclude with some comments about the way the study and the teaching of history can be approached. My argument has several strands: First history is useful in the specifics - sometimes there are stories we should not forget. We owe it to stand witness. Each culture has these je me souvien moments. Some, like Hiroshima or the Holocaust, belong to the whole world. Second, there are stories that it is wise not to forget - we should learn from the blunders of those who came before us and show some wisdom. Finally I argue that historical amnesia is dangerous. Memory is necessary - we need to know who we are if we have any hope of knowing where we are going.

DESCRIPTORS: History of nursing. Memory. Identity.
\end{abstract}

\section{AMNESIA HISTÓRICA Y SUS CONSECUENCIAS - LA NECESIDAD DE CREAR HISTORIAS DE PRÁCTICA}

\begin{abstract}
RESUMEN: Este artículo se centra en dos cuestiones fundamentales: el papel de la historia como un testigo clave de los acontecimientos, los momentos o los cambios en la historia; y el papel de la historia en el actual desarrollo de la identidad - la identidad de los individuos, grupos, naciones y generaciones. Concluyo con algunas observaciones sobre la forma en que el estudio y la enseñanza de la historia puede ser abordada. Mi argumento tiene varias vertientes: en primer lugar, la historia es útil en las especificidades - a veces hay historias que no debemos olvidar. Tenemos esa deuda con los testigos. Cada cultura posee esos momentos de recuerdo. Algunos, como el de Hiroshima o el Holocausto, pertenecen a toda la humanidad. En segundo lugar, existen historias que es sabio no olvidar - nosotros deberíamos aprender con los errores de los que vinieron antes de nosotros y nos mostraron algo de su sabiduría. Por último, demuestro que la amnesia histórica es peligrosa. La memoria es necesaria - necesitamos saber quiénes somos si queremos tener alguna esperanza de saber hacia dónde vamos.
\end{abstract}

DESCRIPTORES: Historia de la enfermería. Memoria. Identidad.

\section{AMNÉSIA HISTÓRICA E SUAS CONSEQUÊNCIAS - A NECESSIDADE DE CONSTRUIR HISTÓRIAS DE PRÁTICA}

RESUMO: Este estudo focaliza dois temas chaves: o papel da história como uma testemunha chave para eventos, momentos ou mudanças na história; e o papel da história no atual desenvolvimento da identidade - identidade de indivíduos, de grupos, de nações ou gerações. Concluirei com alguns comentários sobre o modo como o estudo e o ensino da história podem ser abordados. Meu argumento tem diversas vertentes: primeiro, a história é útil nas especificidades - algumas vezes há histórias que não devemos esquecer. Nós temos essa dívida com as testemunhas. Cada cultura possui esses momentos de lembrança. Alguns como Hiroshima e o Holocausto que pertencem ao mundo inteiro. Segundo, há histórias que é sábio não esquecer - nós deveríamos aprender com os erros daqueles que vieram antes de nós e mostrar alguma sabedoria. Finalmente, demonstro que a amnésia histórica é perigosa. A memória é necessária - nós precisamos saber quem somos e se temos alguma esperança de saber para onde estamos indo.

DESCRITORES: História da enfermagem. Memória. Identidade. 
This essay explores the purpose or function of history. Why it is important and the ways in which it can be approached by teachers and learners to enrich scholarship in nursing and student learning.

I will be focusing on two key themes: the role of history as a witness to key events, moments, or shifts in history; and the role of history in the on-going development of identity - identity of individuals, of groups, of nations or generations. Although the object of the essay is nursing history my comments could apply to medicine and other areas of health care practice equally well. I will conclude with some comments about the way the study and the teaching of history can be approached.

There is a traditional approach to nursing history that has been sustained by non historians in nursing which has been about great women and their achievements..$^{*}$ In scholarly circles this approach has been out of fashion for many decades as its progressivist and teleological assumptions about great women moving the profession forward now seem individualistic and naïve and fail to resonate with more sophisticated social and political analysis that shapes contemporary humanities and social sciences. The challenge for nursing scholars, then, has been to consider what role history content and the academic training that history offers can play in contemporary nursing curricula and its place in the profession at large.

We thus have a disjuncture between the way history is understood by scholars and the way it is embraced by the nursing profession. Traditionally curricula have included brief introductions to nursing history that aim to provide some socialization to students in the early part of their professional education. Although it may be uncommon for students to have a full history course in their degree, in most parts of the world it is usual for there to be some content that looks at the evolution of the profession, speaks of Florence Nightingale and perhaps little else. Typically the curriculum then moves to ethics, standards of practice and so forth. Sadly, the class and the teachers then give a collective sigh of relief, happy to get what is too often the "boring" stuff over with so they can focus on practice and learning skills.

I have great sympathy for both the students and the teachers who struggle to do something interesting with pretty dull material that few people know or care much about. But this raises the questions - what history should we learning? Does it really have to be dull? Why should we bother with the past?

One response to these rhetorical questions is to urge our colleagues teaching the history of nursing to take the approach that we urge upon our students and colleagues in all other areas of scholarship: namely, we urge them to turn to the research literature. It is this literature that we find scholarship seldom reflected in nursing curricula. For instance a quick survey of the major journals that publish nursing history (Nursing History Review and Nursing Inquiry along with various national bulletins of the history of medicine) what one finds is an increasing number of studies on different elements of practice (blood transfusions, typhoid nursing, tuberculosis, world events: wars, disasters, as well as on the professional and legal organization of practice).$^{2-3}$

This more recent shift to write histories of practice can be best exemplified by the work of Julie Fairman Making Room in the Clinic, ${ }^{4}$ and Arlene Keeling Nursing and the Privilege of Prescription 1893-2000, ${ }^{5}$ who have both written excellent histories of the nurse practitioner movement in the United State (US). These histories provide in depth and riveting accounts of the politics and competing tensions of medicine and nursing and how they have played out in the context of the complex public/private service provision in the US.

So there is definitely interesting scholarship out there - but in many respects it is historians talking to other historians, not to nursing students and not to our wider professional community. This lack of conversation indicates a lack of historical literacy, it is an illiteracy that has consequences on the way nursing sees itself and is in turn viewed within the health care system and ultimately by the broader community. Without memory one lacks identity and history is, at least in part, about collective memory.

\section{WITNESS}

So what are the duties and the responsibilities of the historian as memory-keeper? Are there things that we should remember simply because it is important that we do?

Is perhaps the classic example of this style of historiography. Although this work was an excellent and thorough piece of scholarship, its progressivist and teleological assumptions make it dated and of historical interest only. 
This responsibility to remember comes in several common forms.

How do we identify and remember the struggles and achievements of the past? Why do we need to? One answer to this question lies in the relationship between historical narrative and identity. One aspect of this is the need to honour those who struggled to create the possibilities for those who followed. That's the pioneer memory. In many parts of the world it is this particular form of remembering the distinctive sense of history that makes you a Northerner or a Gaucha, or in Canada a Maritimer (from the east coast) I or a prairie person (from the centre). In a country such as Canada or Australia it is the distinctive pioneering story that creates difference in identity, however similar their lifestyles may be today. For some communities it is the harsh history of settlement freezing winters or famine, or slavery and colonization, or struggles for independence become etched into the DNA of its citizens.

My nursing education took place in Darwin - a small city close to Indonesia in the far northwest of Australia. Australia, like Brazil, is a highly urbanized society. Thus there are two places that are "othered" in the Australian psyche: the Centre - which symbolizes the harsh dry interior and desert landscapes, and the North, which represents Aboriginal communities, monsoon, and wilderness. Even though I was from Melbourne, a very European sophisticated city in the south of the country, when I arrived in Darwin I almost immediately began to resent "southerners" who did not understand the difficulties of the north and yet made all the decisions on resources. Along with my peers I developed a distinctive sense of clinical, professional and social identity that constituted the professional community in the far north.

Disasters, too, are very important in collective memory and an illustrative example of identity construction through history. Even though I arrived in Darwin ten years after Cyclone Tracy completely destroyed the city on Christmas Day in 1974, I too developed my Cyclone Tracy stories (along with tales of other cyclones I endured while living in the north). Tracey was such a landmark event that each building, river and street had its story and I, as a member of that community, learned to read the markers of Tracy on my house and garden, I knew how far inland the sea had surged to our street and which buildings and trees had withstood the storm and the sea. I also knew who among my colleagues and clients remained deeply traumatized by grief and fear. These events become part of the narrative about history and place that living and working somewhere creates. That narrative in turn sustains identity.

So remembering events that shape a community or a practice is part of participating in that practice or community. Even if one is unaware of the historical details, the gestalt has been shaped by that history.

There is another element I wish to emphasize on this theme of the need to remember. A few years ago I expressed reluctance in response to an invitation from a friend to see the movie Hotel Rwanda, the 2004 Hollywood movie that depicts the 1994 Rwandan genocide. ${ }^{6}$ That night as I didn't feel up to spending two hours viewing mass slaughter and human horror - and human bravery. My friend's response struck me as very powerful. She said: well you must see it-sooner or later. It is the least we can do. I understood immediately what she meant. The story of Rwanda is an example of the need to bear witness. To know what happened, to feel the pain and helplessness and the guilt of the world community that failed them. It is quite simply necessary that we do not forget what happened.

When a doctoral student, Ryoko O'Hara, was undertaking her oral history of nurses who were survivors of Hiroshima, ${ }^{7}$ both the actually bombing and the horrific aftermath, we talked a great death in historiographical terms about this need to witness. Some things should not be forgotten, To prevent reoccurrence? Some would say this is the reason. I am less idealistic. I think it is simply because we owe it to the dead. Hiroshima is an event the planet needs to remember. In Ryoko O'Hara's wonderful study the overwhelmingly desperate situation, the depiction of young nurses (many only 17 years old) struggling in such hell as their friends and classmates die mysteriously around them, everyone's total ignorance of what had happened, the way they were all measured for side effects as part of scientific investigation by the occupying forces for decades and not provided with treatment, the way many were shunned by Japanese society as unmarriageable ... these are "witness" stories to honour the victims.

When I wrote my history of religious nurses in the $19^{\text {th }}$ century who set up hospitals all around world in often quite remarkable circumstances one of the things that really came home to me was the importance of honoring each other. ${ }^{8}$ This was also a clear distinction between the religious and 
the secular nurses - the religious nurses or nuns understood the importance of sense of community and were supported through letters, prayers and support from their Motherhouse far away. They clearly derived great strength from that support and it enabled them to endure enormous hardship. ${ }^{8}$ The secular nurses were strikingly singular in their suffering and hardship. If one reads their correspondence and diaries it is clear that they felt isolated and burdened, often their correspondence with Miss Nightingale did not provide them with the succor the religious nurses received from their Motherhouse. ${ }^{8}$ It was very tough for them. They starved in Montreal, ${ }^{9}$ were isolated and victims of intrigue in Sydney, martyrs in Liverpool, ${ }^{10}$ the nuns suffered greatly too - but they knew how to mobilize support and build a group to cheer squad them on. They were also very historically minded and wrote all their adventures and hardships back to the motherhouse and the whole community was riveted by their ordeals, prayed for their successes. ${ }^{8}$ It is remarkable how important it was for them. When they died they were honoured and eulogized from parish churches to religious communities around the world. ${ }^{8}$ If you take the case of epidemic nursing - where the religious nurses really came into their own, being a veteran of an epidemic became a badge of pride and honour that followed them their whole lives. Some sisters were extraordinarily heroic (many died in droves) nursing in the cholera and yellow fever epidemics with a singularity of purpose while much of the world around them was gripped by panic. When they eventually died, even if it was 60 years later, the epidemics they had served in and the years etc were always included in the death notices and eulogies. They may have lived as anonymous religious women but their deeds were honored throughout their lives. ${ }^{8}$

Compare this to the recent years and the SARS outbreak. We do not know the names of the nurses and physicians who died, we do not honour those who volunteered to work in those units.

War, sadly, provides the most powerful theme of the intersection of nursing history and national history. For instance there are some quite remarkable prisoner of war stories of Canadian, English and US nurses that really highlight this. Famous Australian stories include the sinking of the Centaur off the coast of Queensland by Japanese submarine, which killed 364 passengers, including 11 nurses. The story of the bravery of Nurse Ellen Savage became a cause célèbre at the time and assisted in harnessing the war effort under an "Avenge the Nurses" campaign. ${ }^{11}$ At the harrowing events where Australian nurses fleeing by hospital ship, the Vyner Brooke, during the invasion of Singapore in February 1942 they were attacked at sea and 12 nurses drowned. Survivors struggled for up to two days to come to shore, once on shore on Banka Island 21 nurses were machine-gunned to death and the remainder imprisoned in a series of increasingly brutal internment camps. Out of the 65 nurses who left Singapore, there were 24 survivors when rescued in 1945. ${ }^{12}$ Nurse Vivian Bullwinkle who was the lone survivor of the massacre lived through her captivity to testify in the War Crimes Commission in Tokyo following the war."*

The importance of these stories was not simply a case of making sure nursing receives the requisite amount of airplay, but that nursing stories are the way in which women become written into a national narrative that has been up to that point entirely male. The story of women at war, in combat, heroism under fire is one that challenged a masculinist national identity and one that in some respects changed society.

War provides the most dramatic example of women moving into centre stage during the twentieth century. In countries such as Australia, New Zealand and Canada, Word War I (WWI) was a key event in the emergence of a national identity and in each case nurses were the only women to play a front-stage role. ${ }^{13-14}$

Heroes are important. They form part of a narrative for a community (in this case nurses, doctors and other health care professionals), and that narrative links in with the broader national or political or gender narrative in critical ways that shape the way we (a global we) see nursing or medicine. This in turn shapes everything from the way the professions are able to recruit people to the field, to the way they are funded and valued.

But if we remember the dead and honour our heroes as part of our duty to witness, we are also performing an act of identity construction. Because

** The Australian War Memorial site gives an excellent overview of the story. http://www.awm.gov.au/ encyclopedia/nurse_survivors/index.asp; http://www.awm.gov.au/encyclopedia/nurse_survivors/ bullwinkel.asp. 
our gods or our saints say as much about ourselves as they do about those we hold in high esteem.

EP Thompson in his landmark text the history of the English Working Class stated that he sought to protect the subjects of his history as from the "great condescension of posterity" ${ }^{15}$ As manual skilled work, and as women's work, nursing too suffers inordinately from the condescension of posterity. ${ }^{16}$ There is no Newtonian glory of standing on the shoulders of giants for nurses. Rather a historical discomfort with the domestic and manual elements of the work (and the links with union/labour history), and more recently a post feminist cringe at the resolutely feminized domestic nature of much of the work. Class and gender are never far away in any analysis of nursing and historians have been gripped by epistemological and methodological debates concerning them. At one time feminist labour history was a major force and in the late 1980s resulting in a flood of excellent histories of women and work. ${ }^{17-18}$ Victorian Studies at that time too favored scholarship on nursing too with great work. ${ }^{19-20}$

But nursing history struggles to receive attention from mainstream historians and yet there are so many important and unanswered questions. Not surprisingly much of scholarly energy comes from gender and women's studies. Within the wider discipline of history and social science structural disinterest in nursing has been a challenge. For examining nursing allows a focus on women at multiple points in society - women and the family - women and economic power such as role of Filipino nurses in a global workforce and the impact on their home country and familial relations, or the the way in which the Rockefeller Foundation's support of nursing in the mid-twentieth century could be the basis of an interesting case study to examine the place of women in the largely male geopolitical frame of mid twentieth century history in Brazil or Finland or Australia. Such questions are supported by recent interest in transnational history which challenges historians to let go of their national boundaries and think of what was happening between states, across states and globally. An interesting question addressed through such an approach might be to look at the effect of Canadian nursing have on the development of nursing in the US. Certainly key early US figures: Adelaide Nutting and Isabel Hampton Robb were both Canadian trained nurses. What about nursing in the Dominion countries (members of the British Empire)? How were the professions and health care shaped by those active networks between members of the British Empire, or the Catholic Church in the $19^{\text {th }}$ and $20^{\text {th }}$ centuries? French scholar Pierre-Yves Saunier does great work in this area describing nursing as a great case study that allows the scholar to explore the links and networks and circulations that exist between countries, continents and empires. ${ }^{21}$

So if knowledge of history makes a difference to what we know about our practice and our profession - in what we understand of our profession and its place in society what should we teach our students?

This is the spot where there is contention. In some countries there is mandated history content in curriculum. Brazil is one such place. In other countries - such as the US and Canada - there are repeated calls for such curricula. But how does core history curriculum play out? Do we have the training and the knowledge to usefully teach history to our students? This is an important question to consider. For many of us, sadly, our experience of nursing history education is not inspiring. Without passion and skill history can become a boring and a set of facts of dubious reliability or relevance. We all know that curricula are overcrowded. It is also highly contentious to think of the content of a core history curriculum. Do students really need to know the dates of Florence Nightingale's life? Some would say yes but many more would answer no. What are the landmarks considered essential for all nurses? What do nurses learn about the history of nursing in their own country or region? Very little as a rule.

There are some interesting resources: wikepedia timeline is an excellent start - it is at least quite international. ${ }^{22}$ Finding out about the non Nightingale history is much harder - and anyone teaching history of nursing needs to find local sources about their nursing history if they wish to engage their students in their own narrative.

But history does not need to be about a person - remarkable or otherwise. Most exciting to me are the non-subject centred histories. It can also be about practice - critical care, and midwifery have done quite well so far ${ }^{23-24}$ I have long wanted to do a history of objects, such as tearable tape, or micropore, and how much practice relies upon it!

Regimes of practice too are extremely amenable to historicization and provide students with important insights into the discursive framing of practice and the importance of power. For instance during the Progressive Era in the 1920s and 1930s 
the scientific management of babies involved no kissing and toilet training beginning at two months with strict feeding by the clock. Authorized both by science and by the state, which felt child rearing was too much of an important job for the nation to be left to parents, nurses played an important role as enforcers of scientific regimen, armed with all power of professional authority ensuring mothers complied with expert advice. ${ }^{25}$ History can be confronting and unsettling as much as it can be reassuring. Good history challenges our assumptions about our contemporary selves by seeing ourselves and practice as a more complex and multiple story. Some of the stories are noble and inspiring, others are skeletons in the cupboard - but they all part of who we are.

History then is not just facts or content it is an approach to data that examines actions and events in the light of context. The analogy with culture is helpful. Whether we choose to give it prominence or not culture dominates - particularly in the world of health care. The way people experience themselves in the world is culturally defined has clear impact on the way we live, what we eat, how we reproduce, raise children etc. This is the world that we as health professionals interface with every day.

Being culture blind is generally considered unforgivable. I would argue that being history blind - or amnesic - creates similar problems. If we do not understand history is it possible to work with Aboriginal and first nation peoples? I think few would dispute the importance of history here. However the same observation plays out endlessly across the whole domain of health care, whether it relates to the regulation of health professions, issues around scope of practice or education, or whether we are talking about the national health care systems. Finally there is a history of practice - the way that we work was not received from on high, but negotiated, experimented and struggled in response to changing conditions, emerging science, shifting needs and service arrangements.

For instance when Nightingale wrote Notes on Nursing her task was to educated women - not health professionals - on the Victorian version of evidence based practice. ${ }^{26}$

In mid Victorian terms that best practice was sanitarianism, a world view that paid attention to hygiene fuelled by the belief that miasma or bad air could contaminate you and make you ill. The understanding of the body under sanitarianism was that the body needed to build the resources to overcome what was taxing it, it did not believe in disease as a result of germs. Thus the role of good nurses was to provide the environment to aid recovery - a topic on which Nightingale was most forthcoming.

Fast forward to the 1920s post WWI and the idea of the hospital and the role of the nurse had been radically transformed. Not only as a result of the professionalizing agenda of nursing itself (regulation etc), but more importantly by science, the rise of hospital based care through major advances in anaesthesia, surgery, plastics, fluid management, disinfection and asepsis. The cure laid not with enabling the body to heal on its own, but in the aggressive management of the body where surgical intervention was promoted and all measures taken to battle with the disease. Insulin, antibiotics and efficient fluid management techniques followed and eventually common medical conditions began to be more effectively managed. The evidence based care of the mid century thus required a very different kind of nurse who needed to manage unstable patients, this lead to the development of Intensive Care Unit, specialized units for intensive nursing!

Much has been written in recent years about the return to community health, home care and the importance of public health and health promotion and the key responsibilities of the system. One of the rarely spoken conundrums is the disconnect that we all participate in as educators where schools are producing nurses educated in a primary health care framework but the workforce demands of the acute care hospitals is driving the political agenda, pushing for increases and is often critical of the fact these new grads are not "work ready". There is a history to this too and one that is striking. In fact it is difficult to turn to a page, and page any year, and not find the same tensions replicated. Archival work brings a profound sense of déjà vu in nursing for the historian. We are still struggling to help government and service providers see that nurses are not an undifferentiated population. When you need a nurse it is not just any nurse, it is a primary health care nurse, or a critical care nurse and they are not interchangeable.

So to summarize my argument here has had several strands.

First history is useful in the specifics - sometimes there are stories we should not forget. We owe it to stand witness. Each culture has these "je me souvien" moments. Some, like Hiroshima or the Holocaust, belong to the whole world. 
There are also stories that it is wise not to forget - we should learn from the blunders of those who came before us and show some wisdom. We should not act as though we came down with the last rain shower. It is wise to learn from our past and try and be wiser. It might also be useful to think of parallels between the aftermath of the Great Depression and the home nursing sector. It was the end of it as families could no longer afford to pay for home care nurses when the economy collapsed. John F. Kennedy said of history that there is no present - just the past rushing forward into the future. If he was correct then amnesia is certainly dangerous. Memory is necessary - we need to know who we are if we have any hope of knowing where we are going.

\section{REFERENCES}

1. Nutting MA, Dock L. A History of Nursing. New York (US): G.B. Putnam's Sons; 1974.

2. Toman C. Blood Work: Canadian Nursing and Blood Transfusion, 1942-1990. Nurs Hist Rev. 2001; 9:51-78.

3. Golden J. A Nurse contracts tuberculosis on the job, 1944-45. Nurs Hist Rev. 2008; 16:209-214.

4. Fairman, J. Making Room in the Clinic. New Jersey (US): Rutgers University Press; 2008.

5. Keeling, A. Nursing and the Privilege of Prescription 1893-2000 Columbus (US): Ohio State University; 2007.

6. Terry George. Hotel Rwanda [movie]. United Artists; 2005.

7. Matsunari Y, NozawaS, Sakata K, Ohara Y, Takahashi K, Hyakuta $Y$, et al. Individual testimonies to nursing care after the atomic bombing of Hiroshima in 1945. Int Nurs Rev. 2008 Mar; 55(1):13-19.

8. Nelson S. Say little do much. Philadelphia (US): University of Philadelphia Press; 2001: 122-3.

9. Helmstadter C. Reforming hospital nursing: the experiences of Maria Machin. Nurs Inq. 2006 Dec; 12(4):249-58.

10. McDonald L, editor. Florence Nightingale on Public Health Care. Ontario (CA): Wilfred Laurier Press; 2004.

11. Australian War Memorial [page on the Internet]. Australia; 1997 [accessed on 2009 Mar 21]. Available at: http:/ / www.awm.gov.au/encyclopedia/ centaur/index.asp
12. Australia's War 1939-1945 [page on the Internet]. Australia; 1997 [accessed on 2009 Mar 21]. Available at: http://www.ww2australia.gov.au/behindwire/ found.html

13. Bassett J. The Australian Army Nursing Service from the Boer War to the Gulf War. Victoria (AU):Oxford University Press; 1992.

14. Meryn S. "Social Sisters: A Feminist Analysis of the Discourses of Canadian Military Nurse Helen Fowlds, 1915-18" in Elliot J, Toman C, Stuart M, editors. Place and Practice in Canadian Nursing History. British Columbia (US): UBC Press; 2008. p. 25-39.

15. Thompson EP. The making of the English working class. Knopf Publishing Group; 1967.

16. Nelson S. Gordon S. The rhetoric of rupture. Nurs Outlook. 2004 Sep-Oct; 52(5):255-61.

17. Reverby S. Ordered to care: The dilemma of American nursing 1850-1945. Cambridge (UK): University Press; 1987.

18. Melosh B. The Physician's hand: work, culture and conflict in American nursing. Philadelphia (US): Temple University Press; 1982.

19. Mary P. Uneven developments: The ideological work of gender in mid-Victorian England. Chicago (US): University of Chicago Press; 1988.

20. Martha V. Independent women: work and community for single women, 1850-1920. Chicago (US): University of Chicago Press; 1985.

21. Saunier PY. Learning by doing: Notes about the making of the Palgrave Dictionary of Transnational History. Journal of Modern European History. 2008; 6(2):159-80.

22. Nursing [homepage on the Internet]. Winkipedia. [accessed 2009 Mar 21]. Available from: http:// en.wikipedia.org/wiki/Nursing

23. Fairman J, Lynaugh JE. Critical Care Nursing: A history. Philadelphia (US): University of Pennsylvania Press; 2000

24. Madonna G. 'From the sphere of Sarah Gampism': the professionalization of nursing and midwifery in the colony of Victoria. Nurs Inq. 2004; 11(3):192.

25. Mein Smith P. Mothers and King Baby: Infant Survival and Welfare in an Imperial World: Australia 1880-1950. London (UK): Macmillan; 1997.

26. Nightingale F. Notes on Nursing: What it is, and what it is not. New York (US): D. Appleton and Company; 1860. 